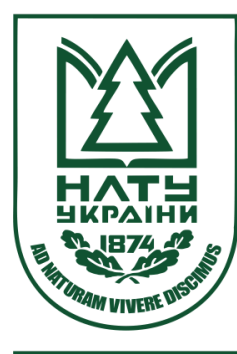

Науковий вісник НлТУ України Scientific Bulletin of UNFU

ISSN 1994-7836 (print)

https://nv.nltu.edu.ua

https://doi.org/10.15421/40280717

Article received 23.08.2018 p.

Article accepted 26.09.2018 p.

удк 544.72, 628.32(349.08)

ISSN 2519-2477 (online)

$@ \bowtie$ Correspondence author

L. V. Sysa

teacher_leon@ukr.net

А. З. Концур, І. З. Думас, Л. В. Сиса

Львівський державний університет безпеки життєдіяльності, м. Львів, Украйна

\title{
ОЧИЩЕННЯ ВОДНИХ СИСТЕМ ВІД НАДЛИШКУ ФОСФАТІВ ЗА ДОПОМОГОЮ БЕНТОНІТУ, АКТИВОВАНОГО НАДВИСОКОЧАСТОТНИМ ВИПРОМІНЮВАННЯМ
}

Вивчено сорбційні властивості бентоніту, опроміненого мікрохвилями, на прикладі вилучення ним фосфат-іонів із концентрованих розчинів. Використано фізико-хімічні методи аналізу та графічно-аналітичну обробку результатів експериментів. Досліджено нативні (необроблені) зразки сорбенту та зразки, опромінені мікрохвилями у два способи: а) попереднє промивання бентоніту чистою водою під дією мікрохвиль ("стимуляція"); б) опромінення мікрохвилями суспензії бентоніту безпосередньо в робочих розчинах фосфатів ("пряме опромінення"). Показано, що останній спосіб активації збільшує сорбційну здатність бентоніту за фосфат-іоном порівняно з нативним та "стимульованим" сорбентом. Криві адсорбції фосфатіонів бентонітом під час "прямого опромінення" розчину мікрохвилями добре описано моделлю Ленгмюра. Гранична рівноважна адсорбція фосфатів (ємність моношару) становить 6,13 мг/г для способу "прямого опромінення", порівняно 3 2,54 мг/г ("стимульований" зразок) та 1,15 мг/г (нативний зразок). Припущено, що внаслідок опромінення суспензії мікрохвилями можливо подолати активаційний бар'єр та зароджуються мікрокристали нерозчинних фосфатів на поверхні кристалів сорбенту. Внаслідок цього різко збільшується сорбційна ємність бентоніту за фосфат-іоном. Відзначено значний вплив кислотності та температури розчину на параметри адсорбції фосфат-іонів бентонітом.

Ключові слова: стічні води; фосфати; очищення; адсорбція; бентоніт; мікрохвилі.

Вступ. Внаслідок неконтрольованого застосування миючих засобів досить часто у стічних водах житловопобутових підприємств є значні кількості фосфат-іонів. Така ситуація є особливою проблемою останнього десятиліття, протягом якого зростання вмісту фосфатів у стічних водах спостерігаємо від 6-8 мг/дм ${ }^{3}$ до 20$25 \mathrm{мг/дм}{ }^{3}$ (Prokopchuk \& Hrubinko, 2007).

Наявні біологічні методи очищення стічних вод не дають змоги досягти необхідного ступеня очищення від сполук фосфору, а загальновідомі фізико-хімічні методи показують доволі гарні результати за ступенем очищення, однак потребують значних витрат (Zapolskyi et al., 2000). 3 огляду на це проблема видалення сполук фосфору із стічних вод на сьогодні не має оптимального вирішення та потребує додаткових досліджень. Окреме місце у цьому напрямі відведено застосуванню природних глинистих матеріалів (зокрема бентоніту) як дешевих, але ефективних сорбентів.

За фазовим мінералогічним складом та хімічною природою бентоніти є складними глинистими алюмосилікатами, у яких поряд $3 \mathrm{Al}_{2} \mathrm{O}_{3}$ та $\mathrm{SiO}_{2}$ присутні також оксиди заліза, лужних та лужноземельних металів. Ці матеріали мають шарувату кристалічну структуру з великою кількістю макро-, мезо- та мікропор і тріщин, у яких можуть сорбуватись найрізноманітніші речовинизабруднювачі (Tarasevich, 1988).
Глинисті сорбенти використовують як напряму, так і після хімічного модифікування або активації. Наприклад, для збільшення кількості та розмірів мікропор ці матеріали обробляють мінеральними кислотами; для збільшення кількості обмінних іонів (здебільшого натрію) - содою; для видалення 3 води іонів важких металів - додають реагенти, які утворюють 3 цими металами важкорозчинні сполуки. В окремих випадках, для покращення сорбційних властивостей природні глини піддають дії ультразвуку, електричного та магнітного полів (Chipriakova, Nigmatullina \& Miasnikov, 2011).

В останні десятиліття перспективним напрямом підвищення ефективності роботи сорбентів є використання для їх активації надвисокочастотного електромагнітного випромінювання (НВЧ ЕМВ, або мікрохвиль). У більшості робіт із цього напряму (Tian et al., 2006; Baldassari et al., 2006; Korichi et al., 2012) вивчали зразки окремих синтетичних сорбентів, опромінених мікрохвилями в різних умовах.

Щодо природних сорбентів, то в роботах (Foletto, Paz \& Gundel, 2013; Surendra et al., 2017) показано, що опромінення бентоніту мікрохвилями призводить до зміни розподілу мікропор на поверхні мінералів, з яких він утворений: монтморилоніту, хлориту, кварцу та ін. Під дією НВЧ ЕМВ у них виникають нові мікротріщини, подрібнюються великі зерна, що значно збільшує

\section{Інформація про авторів:}

Концур Андрій Зіновійович, здобувач. Email: akz.ukr@gmail.com; https://orcid.org/0000-0002-6014-4853

Думас Ірина Зіновіївна, канд. геогр. наук, ст. викладач. Email: iradumas@gmail.com

Сиса Леонід Володимирович, канд. хім. наук, доцент, наук. співробітник НДЛ екобезпеки. Email: teacher_leon@ukr.net; https://orcid.org/0000-0002-3495-2750

Цитування за ДСТУ: Концур А. 3., Думас І. 3., Сиса Л. В. Очищення водних систем від надлишку фосфатів за допомогою бентоніту, активованого надвисокочастотним випромінюванням. Науковий вісник НЛтУ України. 2018, т. 28, № 7. С. 78-82.

Citation APA: Kontsur, A. Z., Dumas, I. Z., \& Sysa, L. V. (2018). Purification of water systems from advantages of phosphates by bentonite activated by ultrahigh-frequency radiation. Scientific Bulletin of UNFU, 28(7), 78-82. https://doi.org/10.15421/40280717

78 Науковий вісник НлтУ України, 2018, т. 28, № 7 Scientific Bulletin of UNFU, 2018, vol. 28, no 7 
площу активної поверхні сорбенту. Відзначено також, що внаслідок дії мікрохвиль на алюмосилікати у водному середовищі відбувається часткове руйнування їх кристалічного каркасу 3 вивільненням силікат-іонів $\mathrm{SiO}_{3}{ }^{2-}$. Ці іони зазнають гідролізу, внаслідок чого зростає $\mathrm{pH}$ водного середовища, в якому відбувається процес активації сорбенту.

У своїй попередній роботі (Kontsur et al., 2016) автори повідомляли, що використання НВЧ ЕМВ для активації бентоніту покращує його сорбційні характеристики стосовно неорганічних іонів (амонію, нітратів, нітритів, фосфатів). Було показано, що сорбція фосфатіонів бентонітом в умовах попереднього експерименту відбувалася так інтенсивно, що виходу графіка рівноважної сорбції на насичення не було досягнуто. Можливо, було використано занадто розбавлені розчини або недостатній час опромінення.

Метою роботи $\epsilon$ вирішення цього питання, а саме вивчення сорбційних параметрів бентоніту за фосфатіонами 3 використанням більш концентрованих робочих розчинів та змінених методик опромінення сорбенту мікрохвилями.

Методики виконання дослідження. У теперішніх експериментальних дослідженнях використано той самий зразок бентоніту, що і в попередній роботі (Kontsur et al., 2016) - порошок тонкого помелу, придбаний у загальній торговельній мережі ("комерційний").

Вивчення сорбційних параметрів цього матеріалу за фосфат-іонами здійснено на прикладі трьох серій зразків бентоніту:

1) "нативний" (використано "комерційний" бентоніт без жодного попереднього оброблення; серія "нат");

2) "стимульований" (промитий малою кількістю дистильованої води 3 одночасним опроміненням НВЧ ЕМВ протягом 120 с; серія "стим");

3 ) "прямого опромінення" ("комерційний" бентоніт без попередньої підготовки змішаний з робочим розчином фосфату та опромінений НВЧ ЕМВ протягом 300 с; т. зв. "Direct Irradiation"; серія "DIR").

Джерелом НВЧ ЕМВ був генератор на магнетроні моделі М-105, який розробили та виготовили автори. Докладніше схему установки описали автори раніше (Kontsur et al., 2016).

Концентрації фосфат-іонів у модельних та робочих розчинах визначались фотоколориметрично за відомою стандартною методикою - 3 комбінованим "молібденовим реактивом" та аскорбіновою кислотою (Dmytryev et al., 1989). Для цього використовували спектрофотометр Spekromom 195D та концентраційний фотоколориметр КФК-2. Камеральне опрацювання результатів експерименту здійснювали за класичними методиками (Subramanyam \& Das, 2014) з використанням стандартних процедур пакету Microsoft Office Excel.

Експериментальні числові концентрації фосфатіонів та побудовані на їх основі криві адсорбції опрацьовано згідно з вимогами статистичного аналізу. Розраховано суми абсолютних відхилень (САВ), суми квадратичних відхилень (СКВ), середні відносні відхилення (CBB), суми стандартних відхилень (CCB) та $\mathrm{R}^{2}$.

Розглядали різні варіанти лінійної регресії, які відповідають відомим моделям адсорбції: ізотерми Ленгмюра, Фрейндліха, Редліха-Петерсона та ЛенгмюраФрейндліха (Subramanyam \& Das, 2014). Модель, яка найкраще описувала набір експериментальних даних, було обрано за мінімальною сумою стандартних відхилень (ССВ). Відповідну ізотерму адсорбції використовували для розрахунку граничної адсорбційної ємності бентоніту.

Модельні розчини фосфат-іонів ("моделі") виготовляли 3 підсушених наважок дигідрогенфосфату калію кваліфікації "ч" та дистильованої води, а робочі розчини (які, власне, і піддавались сорбційному очищенню) способом кратних розбавлень відповідного об'єму "моделі" дистильованою водою.

Сорбційні властивості бентоніту, як і в попередніх роботах авторів (Kontsur et al., 2016; Sysa et al., 2017), вивчали у статичних умовах. Для цього в конічні скляні колби місткістю 250 мл поміщали по 1,0 г "комерційного" бентоніту. Далі, у серіях "нат" і "DIR", заливали в колби з сорбентом по 100 мл відповідних робочих розчинів фосфатів, а в серії "стим" - по 30 мл дистильованої води. Подальші кроки:

• у серії "нат": отримані суспензії перемішували та залишали для відстоювання;

- у серії "стим": колби із суспензіями бентоніту в дистильованій воді опромінювали мікрохвилями протягом 120 с та відстоювали 30 хв; промивну воду видаляли за допомогою вакуумної помпи; заливали отриманий "стимульований" сорбент робочими розчинами фосфатів (100 мл); перемішували та залишали для відстоювання;

• cерії "DIR": суспензії нативного бентоніту в робочих розчинах фосфатів одразу опромінювали мікрохвилями протягом 300 с; перемішували та залишали для відстоювання.

Потім у всіх серіях тричі повторювали перемішування 3 інтервалом в 1 год і залишали на ніч. Загальний час контакту сорбенту з робочими розчинами в кожній серії становив близько 24 год. Після відстоювання 3 колб відбирали аліквоти очищених робочих розчинів та аналізували їх на вміст фосфат-іонів.

Повний комплекс експериментальних досліджень у межах нашої роботи проводили у НДЛ екобезпеки ЛДУ БЖД (свід. метр. атест. № РЛ 127/17 від 14.11.2017 р.).

Результати дослідження та їх обговорення. На основі отриманих значень концентрацій фосфат-іонів у робочих розчинах до та після сорбційного очищення здійснено побудову кривих адсорбції та розрахунки сорбційних параметрів бентоніту.

Зокрема, для кожної описаної вище серії сорбенту побудовано графіки залежності величини адсорбції ( $A$, мг/г) від рівноважної концентрації розчину (c, мг/дм $\left.{ }^{3}\right)$ за формулою (1)

$$
A=\frac{c_{0}-c}{m} V,
$$

де: $c_{0}$ - початкова концентрація фосфат-іону в робочому розчині, мг/дм³ $V$ - об'єм робочого розчину, дм ${ }^{3}$; $m$ - наважка сорбенту, г.

Статистичне оброблення вихідних даних та отриманих кривих адсорбції фосфат-іонів на бентоніті вказала на модель Ленгмюра, як таку, що описує ці криві 3 найменшою сумою стандартних відхилень (ССВ). За лінеаризованим варіантом основного рівняння цієї моделі (формула (2)) розраховано значення граничної молекулярної адсорбції ( $A_{\infty}-\epsilon$ мність моношару, мг/г) та константу адсорбційної рівноваги $(K)$.

$$
\frac{c}{A}=\frac{1}{A_{\infty} K}+\frac{1}{A_{\infty}} c .
$$

Первинні ізотерми Ленгмюра та їх лінеаризовані варіанти побудовано окремо для кожної серії, однак на 
рисунку їх зведено разом для зручності зіставлення. На цьому ж рисунку показано частину результатів попередньої роботи авторів (Kontsur et al., 2016), в якій вони вивчали сорбцію фосфатів нативним та "стимульованим" бентонітом із розбавлених розчинів.

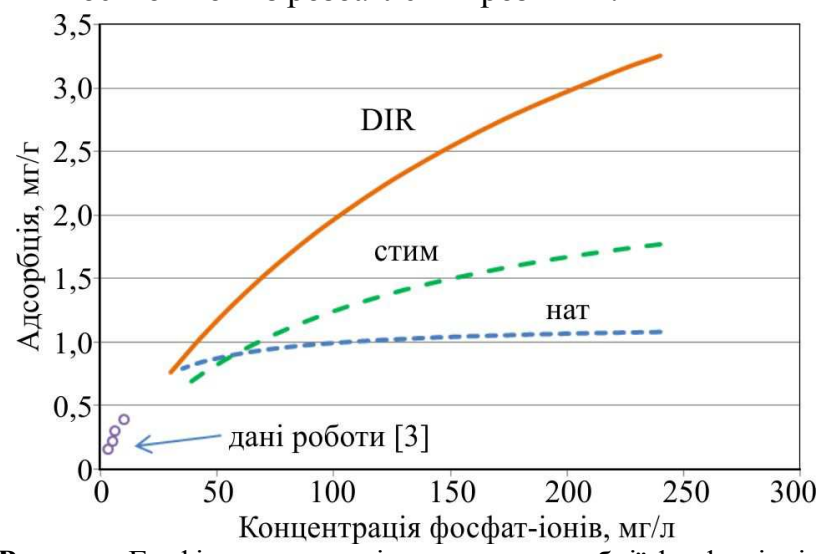

Рисунок. Графіки залежності величини адсорбції фосфат-іонів на бентоніті на різних серіях підготовки сорбенту: "нат" - без попереднього оброблення ("комерційний"); "стим" - промитий водою під дією мікрохвиль; "DIR" - опромінений мікрохвилями в робочому розчині.

У таблиці вказано значення сорбційних параметрів бентоніту в різних варіантах його попередньої підготовки, розраховані за відповідними лінеаризованими ізотермами Ленгмюра.

Таблиця. Значення граничної адсорбції $\left(\mathbf{A}_{\infty}\right)$, константи адсорбційної рівноваги (К) та результати статистичної обробки кривих адсорбції фосфат-іонів на бентоніті за різних варіантів його попереднього оброблення

\begin{tabular}{|c|c|c|c|c|c|}
\hline $\begin{array}{c}\text { № } \\
\text { 3/п }\end{array}$ & Серія & $\begin{array}{c}\text { Гранична адсор- } \\
\text { бція }\left(A_{\infty}\right), \text { мг/ } /\end{array}$ & $\begin{array}{c}\text { Константа адсор- } \\
\text { бційної рівноваги }(K)\end{array}$ & $\begin{array}{c}\text { СC } \\
\text { В }\end{array}$ & $R^{2}$ \\
\hline 1 & "нат" & 1,15 & 0,063 & 5,42 & 0,98 \\
\hline 2 & "стим" & 2,54 & 0,010 & 3,84 & 0,96 \\
\hline 3 & "DIR" & 6,13 & 0,005 & 2,12 & 0,97 \\
\hline
\end{tabular}

Як видно з отриманих результатів, "пряме опромінення" бентоніту мікрохвилями в процесі сорбційного очищення ним водних розчинів від фосфат-іонів збільшує сорбційні характеристики цього матеріалу в декілька разів. Пояснити такий ефект можна в такий спосіб.

У зазначених вище роботах (Foletto, Paz \& Gundel, 2013; Surendra et al., 2017) відзначено, що НВЧ ЕМВ спричиняе інтенсивні коливання сорбованих молекул (диполів) води. У випадку вологих алюмосилікатних сорбентів (зокрема глинистих) це призводить до випаровування води, а також до часткового руйнування поверхневих частин алюмосилікатного каркасу. Саме внаслідок таких перетворень (відкриття тупикових пор, збільшення кількості та розмірів мікропор на поверхні) можуть покращитись сорбційні параметри алюмосилікатних сорбентів.

Ці ж автори виявили, що разом із частковим руйнуванням поверхні в алюмосилікатних мінералах відбувається розрив зв'язків у "сіольних" групах $\equiv \mathrm{Si}-\mathrm{OH}$. Останній процес, а також гідроліз утворених після руйнування каркасу силікат-іонів $\mathrm{SiO}_{3}{ }^{2-}$, призводять до збільшення кількості "вільних" гідроксильних груп (тобто до зростання рН розчину).

На нашу думку, мікрохвильове опромінення суспензії сприяє набагато інтенсивнішому, ніж просто теплове, перемішуванню, та виникненню біля поверхні сорбенту складних багатофазних композицій: молекули води, фосфат-іони, гідроксид-іони, силікат-іони, іони ме- талів, частково вивільнені з алюмосилікатного каркасу тощо. 3 такого набору субмолекулярних часток дуже ймовірним є утворення нової кристалічної фази, адже багато фосфатів металів є важкорозчинними.

У процесі "прямого опромінення" суспензії, біля поверхні сорбенту в короткі моменти часу створюються саме такі сприятливі умови, коли у певних мікрооб'ємах розчину виникає той же хімічний склад і наближена псевдокристалічна будова (метафаза), які відповідають за складом і будовою майбутній твердій речовині (наприклад, зародку нерозчинного фосфату).

Саме мікрохвилі можуть надати цим дуже динамічним субмолекулярним системам додаткову енергію для подолання активаційного бар'єру і переходу зі стану метафази у початковий мікрозародок кристалу.

Внаслідок такої мікрокристалізації фосфат-іони виводяться з розчину не тільки за рахунок "класичної" фізичної адсорбції у вигляді моношару на поверхні мікропор у кристалах бентоніту, а й за рахунок новоутворених мікрокристалів нерозчинних фосфатів металів (наприклад, алюмінію, кальцію або магнію). Це й призводить до різкого зростання сорбційних параметрів бентоніту за фосфат-іоном у серії "прямого опромінення".

Підтвердити або заперечити утворення мікрокристалів нерозчинних фосфатів у процесі опромінення мікрохвилями суспензії бентоніту можна було б за допомогою ренгенофазового та ренгеноструктурного аналізів, скануючої електронної мікроскопії тощо, однак для таких досліджень потрібні значно більші кількості адсорбованої фази. Саме тому оптимізація процесу оброблення суспензій сорбенту НВЧ ЕМВ (конструкційні особливості установки, порядок та спосіб опромінення, його тривалість, потужність, а можливо, і частота хвилі) $є$ основним завданням авторів на наступних етапах досліджень.

Безсумнівним $є$ вплив температури розчину на процес сорбції. Однак експериментально дослідити залежність сорбційних параметрів опроміненого бентоніту від температури суспензії на сучасному етапі не можливо через те, що сама суспензія сильно нагрівається у процесі мікрохвильового опромінення. Подібна ситуація виникає, якщо спробувати експериментально вивчати залежність параметрів сорбції фосфат-іонів на опроміненому бентоніті від $\mathrm{pH}$ розчину.

На прикладі сорбентів-цеолітів (Matsuska, Sydorchuk \& Sabadash, 2014) встановлено, що фосфати краще сорбуються у кислому середовищі. За низьких рН відбувається хімічна взаємодія протона 3 цеолітовим каркасом, що супроводжується вивільненням натрію в розчин. Паралельно відбувається руйнування поверхневого шару цеоліту, звільнення нових сорбційних центрів цеоліту, що розташовані в об'ємі цеоліту, збільшення сорбційної здатності за рахунок відкриття тупикових пор та збільшення діаметра мікропор. Ймовірно, що при цьому в кристалічній гратці утворюється стійкий та важкорозчинний фосфат алюмінію $\mathrm{AlPO}_{4}$.

У лужному середовищі у випадку сорбції двох- та трьохзаміщеного калій фосфату відбувається заміщення калію на натрій та кальцій. При цьому кальцій взаємодіє 3 гідрофосфат- та фосфат-іоном з утворенням стехіометричних та нестехіометричних кальцій гідроксилапатитів. Як було зазначено вище, у нашому випадку (сеpiï "стим" та "DIR") сам процес опромінення вже приводить до вивільнення груп $\mathrm{OH}^{-}$(зростання $\mathrm{pH}$ середови- 
ща), тому кількісно прослідкувати залежність сорбційних параметрів опроміненого бентоніту від кислотності розчину є досить складним завданням. Проте, у будь-якому випадку, можна стверджувати, що "пряме опромінення" суспензії бентоніту сприяє набагато ефективнішому виведенню фосфат-іонів із водних розчинів.

Окрім викладено вище, порівняно 3 процесом попередньої "стимуляції" сорбенту, процес "прямого опромінення" значно спрощує процедуру очищення розчинів, оскільки відпадає необхідність у проміжній промивці бентоніту (відстоювання та видалення промивної води).

\section{Висновки:}

1. Фізико-хімічними методами аналізу та графічно-аналітичною обробкою результатів експериментів вивчено сорбційні параметри природного бентоніту за фосфатіонами в умовах їх високих концентрацій.

2. Досліджено сорбційні властивості як нативні (необроблені) зразки сорбенту, так і опромінені мікрохвилями у два способи: попередня промивка бентоніту чистою водою під дією НВЧ ЕМВ ("стимуляція") та опромінення мікрохвилями суспензії бентоніту безпосередньо в робочих розчинах, які містять значні кількості фосфатів ("пряме опромінення").

3. Показано, що спосіб "прямого опромінення" значно покращує сорбційну здатність бентоніту за фосфатіоном, порівняно з варіантами нативного та "стимульованого" сорбенту.

4. Розраховано за лінеаризованим рівнянням Ленгмюра граничну рівноважну адсорбцію фосфатів (ємність моношару), що становить 6,13 мг/Г для способу "прямого опромінення", порівняно з 2,54 мг/г ("стимульований" зразок) та 1,15 мг/Г (нативний зразок).

5. Запропоновано наближену модель поведінки багатофазної водно-іонної композиції біля поверхні алюмосилікатних кристалів сорбенту під дією НВЧ ЕМВ, внаслідок якої можливо подолати активаційний бар'єр для зародження мікрокристалів нерозчинних фосфатів та різко збільшується сорбційна ємність бентоніту за фосфат-іоном.

6. Припущено, що значний вплив на параметри адсорбції фосфат-іонів бентонітом можуть здійснювати кислотність та температура розчину, а також потужність i тривалість НВЧ-опромінення.

\section{Перелік використаних джерел}

Baldassari, S., Komarneni, S., Mariani, E., \& Villa, C. (2006). Microwave versus conventional preparation of organoclays from natural and synthetic clays. Applied Clay Science, 31, 134-141. https://doi.org/10.1016/i.clay.2005.09.005

Chipriakova, A. P., Nigmatullina, A. A., \& Miasnikov, S. K. (2011). Primenenie bentonita pri ochistke vody v sovmeshhennom kristallizatcionno-adsorbtcionnom protcesse s ultrazvukovoi intensifikatciei. (Vol. 25). Uspekhi v khimii i khimicheskoi tekhnologii, 1(117), 102-108. [In Russian].

Dmytryev, M. M., Kaznyna, N. Y., \& Pynyhyna, Y. A. (1989). Sanytarno-khymycheskyi analyz zahriazniaiushchykh veshchestv $v$ okruzhaiushchei srede. Moscow: Khymyia, 348 p. [In Russian].

Foletto, E. L., Paz, D. S., \& Gundel, A. (2013). Acid-activation assisted by microwave of a Brazilian bentonite and its activity in the bleaching of soybean oil. Applied Clay Science, 83(84), 63-67. https://doi.org/10.1016/j.clay.2013.08.017

Kontsur, A. Z., Karpyak, O. R., \& Sysa, L. V. (2016). Some peculiarities of bentonite regeneration by means of using high-frequency emanation (on the example of biogenic ions). Scientific Bulletin of UNFU, 26(8), 292-298. https://doi.org/10.15421/40260845

Korichi, S., Elias, A., Mefti, A., \& Bensmaili, A. (2012). The effect of microwave irradiation and conventional acid activation on the textural properties of smectite: Comparative study. Applied Clay Science, 59(60), 76-83. https://doi.org/10.1016/j.clay.2012.01.020

Matsuska, O. V., Sydorchuk, O. V., \& Sabadash, V. V. (2014). Adsorbtsiia fosfativ pryrodnymy ta modyfikovanymy sorbentamy iz vodnykh rozchyniv. (Vol. 16, part 3). Scientific Bulletin LNUVMBT imeni S. Z. Gzhytskoho, 3(60), 342-347. [In Ukrainian].

Prokopchuk, O. I., \& Hrubinko, V. V. (2007). Fosfaty u vodnykh ekosystemakh. Ternopil: TNPDU, 124 p. [In Ukrainian].

Subramanyam, B., \& Das, A. (2014). Linearised and non-linearised isotherm models optimization analysis by error functions and statistical means. Journal of Environmental Health Science and Engineering, 12, 92. https://doi.org/10.1186/2052-336X-12-92

Surendra, B. S., Veerabhadraswamy, M., Anil kumar H. G., Kendagannaswamy, B. K., Nagaswarupa, H. P., \& Prashanth, S. C. (2017). Microwave assisted physico-chemical modification of Bentonite clay: characterization and photocatalytic activity. Materials Today: Proceedings, 4, 11727-11736. https://doi.org/10.1016/j.matpr.2017.09.089

Sysa, L. V., Rudyk, Yu. I., \& Kontsur, A. Z. (2017). Analiz izoterm adsorbtsii ioniv tsynku na bentoniti pislia obroblennia yoho nadvysokochastotnym vyprominiuvanniam. Ekolohichna bezpeka, 2(24), 45-51. [In Ukrainian].

Tarasevich, Iu. I. (1988). Stroenie i khimiia poverkhnosti sloistykh silikatov. Kyiv: Naukova dumka, 248 p. [In Russian].

Tian, B., Liu, X., Yang, H., Xie, S., Yu, C., Tu, B., \& Zhao, D. (2006). General Synthesis of Ordered Crystallized Metal Oxide Nanoarrays Replicated by Microwave-Digested Mesoporous Silica. Advanced materials, 15(15), 1370-1374.

Zapolskyi, A. K., Mishkova-Klymenko, M. A., Astrelin, I. M., et al. (2000). Fizyko-khimichni osnovy tekhnolohii ochyshchennia stichnykh vod. Kyiv: Libra, 552 p. [In Ukrainian].

А. З. Концур, И. З. Думас, Л. В. Сыса

Львовский государственный университет безопасности жизнедеятельности, г. Львов, Украина

\title{
ОЧИЩЕНИЕ ВОДНЫХ СИСТЕМ ОТ ИЗБЫТКА ФОСФАТОВ С ПОМОЩЬЮ БЕНТОНИТА, АКТИВИРОВАННОГО СВЕРХВЫСОКОЧАСТОТНЫМ ИЗЛУЧЕНИЕМ
}

\begin{abstract}
Изучены сорбционные свойства бентонита, облученного микроволнами, на примере извлечения им фосфат-ионов из концентрированных растворов. Применены физико-химические методы анализа и графически-аналитическая обработка результатов экспериментов. Исследованы нативные (необработанные) образцы сорбента и образцы, облученные микроволнами в два способа: а) предварительная промывка бентонита чистой водой под воздействием микроволн ("стимуляция"); б) облучение микроволнами суспензии бентонита непосредственно в рабочих растворах фосфатов ("прямое облучение"). Показано, что последний способ активации увеличивает сорбционную способность бентонита по фосфат-иону по сравнению с нативным и "стимулированным" сорбентом. Кривые адсорбции фосфат-ионов бентонитом при "прямом облучении" раствора микроволнами хорошо описываются моделью Ленгмюра. Предельная равновесная адсорбция фосфатов (ёмкость монослоя) составляет 6,13 мг/Г для способа "прямого облучения", по сравнению с 2,54 мг/Г ("стимулированный" образец) и 1,15 мг/г (нативный образец). Высказано предположение, что в результате облучения суспензии микроволнами становится возможным преодоление активационного барьера и зарождение микрокристаллов нерастворимых фосфатов на поверхности кристаллов сорбента. Вследствие этого резко возрастает сорбционная ёмкость бентонита по фосфат-иону. Отмечено значительное влияние кислотности и температуры раствора на параметры адсорбции фосфат-ионов бентонитом.
\end{abstract}

Ключевые слова: сточные воды; фосфаты; очистка; адсорбция; бентонит; микроволны. 


\section{PURIFICATION OF WATER SYSTEMS FROM ADVANTAGES OF PHOSPHATES BY BENTONITE ACTIVATED BY ULTRAHIGH-FREQUENCY RADIATION}

The sorption properties of natural bentonite irradiated with microwaves were studied on the sample of the removal of phosphate ions from concentrated solutions. Physical and chemical methods of analysis and graphical-analytical processing of experimental results are used. The bentonite sorption parameters are determined in static conditions. The concentration of phosphate ions in working solutions before and after sorption purification is determined by photometric method. Bentonite samples were used as sorbent in various preliminary preparations. The first option is a native (unprocessed) sample; the second option is bentonite activated by washing it with pure water under the action of a microwave ("stimulated"); the third option - microwave irradiation of the bentonite suspension is made directly in the working solutions of phosphates ("direct irradiation"). It is shown that the latter method of activation significantly increases the sorption capacity of bentonite by phosphate ion compared to the native and "stimulated" sorbent. The adsorption curves of phosphate ions by bentonite with "direct irradiation" of the solution by microwaves are well described by the Langmuir model. The boundary equilibrium adsorption of phosphates (monolayer capacity) is $6.13 \mathrm{mg} / \mathrm{g}$ for the "direct irradiation" method, compared to $2.54 \mathrm{mg} / \mathrm{g}$ ("stimulated" sample) and $1.15 \mathrm{mg} / \mathrm{g}$ (native sample). It is suggested that as a result of irradiation of the microwave suspension, it is possible to overcome the activation barrier and the emergence of microcrystals of insoluble phosphates on the surface of the sorbent crystals. As a result, the sorption capacitance of bentonite by phosphate ion increases sharply. Significant influence of acidity and temperature of the solution on adsorption parameters of phosphate ions by bentonite is noted. The result of the study is a quantitative assessment of the positive effect of microwave irradiation on improving the sorption parameters of bentonite as a promising sorbent for the purification of wastewater from excess phosphates. Further work in this direction should be directed to establish a clear influence of power, duration, frequency and other characteristics of ultrahigh-frequency radiation on the sorption characteristics of natural sorbents.

Keywords: sewage; phosphates; purification; adsorption; bentonite; microwaves. 